\title{
Unilateral optic disc swelling associated with idiopathic hypertrophic pachymeningitis: a rare cause for a rare clinical finding
}

\author{
Rajesh Shankar lyer, ${ }^{1}$ S Padmanaban, ${ }^{2}$ Manoj Ramachandran ${ }^{2}$
}

${ }^{1}$ Department of Neurology, KG Hospital, Coimbatore, Tamil Nadu, India 2Department of Ophthalmology, KG Hospital, Coimbatore, Tamil Nadu, India

\section{Correspondence to} Dr Rajesh Shankar lyer, dr_rsh@hotmail.com

Accepted 12 March 2017

\section{(a) CrossMark}

To cite: Shankar lyer $R$, Padmanaban $\mathrm{S}$,

Ramachandran M. BMJ Case Rep Published online:

[please include Day Month

Year] doi:10.1136/bcr-2017219559

\section{DESCRIPTION}

A woman aged 28 years presented with a 1-year history of left-sided headache. The headache was continuous and interfering with activities of daily living. She did not have vomiting or visual obscurations. She developed left-sided sixth nerve palsy and facial numbness and was referred to us. On clinical evaluation, she had left-sided sensorineural deafness. Fundus examination showed optic disc swelling on the left side and a normal right eye (figure 1A). MRI brain with contrast showed features of hypertrophic pachymeningitis predominantly affecting the left side involving the tentorium and cerebral cortex (figure $1 \mathrm{~B}, \mathrm{E}$ ) and encasing the cavernous sinus (figure $1 \mathrm{C}, \mathrm{D}$ ). Optic nerve sheath dilation was evident on the left side (figure 1F, G). Blood counts, serum biochemical tests and erythrocyte sedimentation rate were normal. The serum was negative for rheumatoid factor, antinuclear antibodies and antidouble-stranded DNA. The serum VDRL test and hepatitis B surface antigen were negative. Work up for neurosarcoidosis including chest CT scan, serum calcium and ACE were negative. A CT scan of the abdomen did not reveal evidence for a neoplastic or a chronic inflammatory disease. The cerebrospinal fluid (CSF) pressure measured at lumbar puncture was normal at $12 \mathrm{~cm} \mathrm{H}_{2} \mathrm{O}$. The CSF showed mild lymphocytic pleocytosis, normal biochemical values and was negative for malignant cells. Microbiological evaluation of the CSF for cryptococcal antigen and VDRL was negative. The
CSF culture for fungi and acid-fast bacilli was also negative. Dural biopsy showed meningeal thickening and non-specific chronic inflammation and lacked features of granuloma or vasculitis. The biopsy specimen was negative for acid-fast bacilli and fungal stains. A diagnosis of idiopathic hypertrophic pachymeningitis (IHPM) was made based on the neuroradiological findings of thickened dura, histopathological findings of non-specific inflammation and exclusion of known causes of chronic inflammation. She was initiated on oral prednisone $1 \mathrm{mg} / \mathrm{kg} /$ day. At 3 months follow-up, she was headache-free and the optic disc swelling had resolved. She is being maintained on azathioprine and low-dose steroids.

Papilloedema refers to optic disc swelling in the presence of raised intracranial pressure (ICP). ${ }^{1}$ In the absence of raised ICP, it is referred to as disc oedema. Unilateral optic disc oedema in the setting of normal ICP as seen in our case is caused by ischaemia (eg, anterior ischaemic optic neuropathy, retinal vein occlusion) and demyelination (eg, multiple sclerosis) of the optic nerve and diabetic papillopathy. ${ }^{2}$ It can also be due to direct compression of the optic nerve due to intracranial lesions like sphenoidal meningioma, optic-nerve glioma and pituitary adenoma where the disc swelling is ipsilateral to the lesion. In our patient, IHPM was causing the compression resulting in ipsilateral disc swelling and multiple cranial nerve palsies. To the best of our knowledge, this inflammatory lesion is 
not reported to be associated with unilateral disc oedema. Our case reiterates the importance of brain imaging in all patients with unilateral optic disc swelling. Inflammatory lesions like

Learning points

- Careful evaluation of optic fundus on both sides should be performed in every case of headache.

- The presence of unilateral optic disc swelling also warrants further evaluation with neuroimaging.

- Medically manageable ipsilateral intracranial inflammatory lesions like idiopathic hypertrophic pachymeningitis can also present as unilateral optic disc swelling.
IHPM which can be medically managed should also be considered along with other tumours as mentioned above while evaluating a patient with this clinical presentation.

Contributors RSI conceived the idea and designed the paper. SP reported the eye finding and helped in finalising the draft. MR helped in interpretation of the eye finding and contributed in the reporting.

Competing interests None declared.

Patient consent Obtained.

Provenance and peer review Not commissioned; externally peer reviewed.

\section{REFERENCES}

1 Huna-Baron R, Landau K, Rosenberg M, et al. Unilateral swollen disc due to increased intracranial pressure. Neurology 2001;56:1588-90.

2 Van Stavern GP. Optic disc edema. Semin Neurol 2007;27:233-43.

Copyright 2017 BMJ Publishing Group. All rights reserved. For permission to reuse any of this content visit http://group.bmj.com/group/rights-licensing/permissions.

BMJ Case Report Fellows may re-use this article for personal use and teaching without any further permission.

Become a Fellow of BMJ Case Reports today and you can:

- Submit as many cases as you like

- Enjoy fast sympathetic peer review and rapid publication of accepted articles

- Access all the published articles

- Re-use any of the published material for personal use and teaching without further permission

For information on Institutional Fellowships contact consortiasales@bmjgroup.com

Visit casereports.bmj.com for more articles like this and to become a Fellow 